\title{
PENGARUH BIAYA PEMASARAN TERHADAP PENDAPATAN PEDAGANG PENGUMPUL KELAPA BUTIR (Cocos nucifera, L) DI KECAMATAN PEUREULAK BARAT KABUPATEN ACEH TIMUR
}

\author{
Oleh \\ Siti Balqies Indra, SP, MP1/Abdullah² \\ ${ }^{1}$ Dosen Tetap Program Studi Agribisnis Fakultas Pertanian \\ 2Mahasiswa Fakultas Pertanian Program Studi Agribisnis \\ Universitas Samudra, Langsa-Aceh
}

\section{Abstrak}

Pengaruh Biaya Pemasaran Terhadap Pendapatan Pedagang Pengumpul Kelapa Butir (Cocos nucifera, L) Kecamatan Peureulak Barat Kabupaten Aceh TimurTujuan penelitian ini adalah untuk mengetahui pengaruh biaya pembelian. buah kelapa butir dan biaya pengangkutan terhadap pendapatan pedagang pengumpul buah kelapa butir di Kecamatan Peureulak Barat Kabupaten Aceh Timur. Metode penelitian yang digunakan dalam penelitian ini adalah metode survey. Penentuan sampel dilakukan dengan menggunakan metode Sensus dengan jumlah sampel yang diambil sebanyak 15 orang. Lokasi penelitian ini dilaksanakan di Kecamatan Peureulak Barat Kabupaten Aceh Timur. Waktu peneltian dilakukan pada bulan Oktober sampai dengan Nopember 2014.

Hasil perhitungan regresi linear berganda, sehingga diperoleh persamaan regresi sebagai berikut : $\mathrm{Y}=$ 4,87 + 0,201X1 - 0,103X2. Dari persamaan regresi dapat disimpulkan bahwa : “ Setiap penambahan Rp. 1.000.000,00,- biaya pembelian kelapa maka pendapatan pedagang pengumpul kelapa butir bertambah Rp. 201.000,00,-, dan setiap penambahan Rp. 1.000.000,00,- biaya pengangkutan kelapa maka pendapatan pedagang pengumpul kelapa berkurang Rp. 103.000,00,-. Dari perhitungan diperoleh (R2) = 0,547 atau 54,7 $\%$. Ini berarti biaya pembelian kelapa dan biaya pengangkutan kelapa berpengaruh terhadap pendapatan sebesar 54,7 \% sedangkan 45,3 \% dipengaruhi oleh faktor-faktor lainnya yang tidak diteliti dalam penelitian ini. Hasil pengujian secara serempak diperoleh Fcari = 7,237 dengan Ftabel 3,89 pada tingkat kepercayaan $95 \%$ dan 6,93 pada tingkat $99 \%$. Ini berarti secara serempak ada pengaruh yang sangat nyata antara biaya pembelian kelapa dan biaya pengangkutan kelapa terhadap pendapatan pedagang pengumpul kelapa butir di Kecamatan Peureulak Barat Kabupaaten Aceh Timur.

Hasil pengujian signifikan secara parsial dilakukan dengan uji t, dimana hasil dari pengujian pada parameter X1 dan X2 diperoleh hasil sebagai berikut : “ tcari untuk t1sebesar 33,294 dengan ttabel 1,78 pada tingkat kepercayaan $95 \%$ dan 2,68 pada tingkat $99 \%$ (ttabel $\alpha 0,05<$ tcari>ttabel $\alpha 0,01$ ) . maka terima Ha dan tolak Ho. Artinya secara parsial biaya pembelian berpengaruh sangat nyata terhadap pendapatan pedagang pengumpul kelapa butir. Dan tcari untuk t2 sebesar -0,017 dengan ttabel 1,78 pada tingkat kepercayaan $95 \%$ dan 2,68 pada tingkat $99 \%$ (ttabel $\alpha 0,05>$ tcari<ttabel $\alpha 0,01$ ). maka terima Ho dan tolak Ha. Artinya secara parsial biaya pengangkutan kelapa tidak berpengaruh terhadap pendapatan pedagang pengumpul kelapa butir. Kata Kunci; Kelapa, Pemasaran, Biaya, Margin, Pendapatan, Efisiensi

\section{PENDAHULUAN}

\section{Latar Belakang}

Indonesia merupakan salah satu Negara yang tergolong kedalam Negara agraris. Karena sebagian besar penduduknya menggantungkan hidupnya pada sektor pertanian, sehingga sektor pertanian harus mendapat perhatian yang besar dari pemerintah. Kegiatan dibidang pertanian, mulai dari budidaya tanaman pangan, peternakan, perikanan, kehutanan, dan perkebunan. Salah satu tanaman perkebunan yang berkembang adalah kelapa.

Petani sebagai produsen kelapa memegang peranan penting didalam menghasilkan 
buah kelapa yang dapat dijual kepada konsumen, baik untuk memenuhi pasar lokal, regional, nasional dan internasional. Kebutuhan buah kelapa setiap tahunnya terus bertambah sesuai dengan perubahan jumlah penduduk dan perubahan pendapatan masyarakat, zaman, dimana kelapa dijadikan sebagai bahan baku untuk berbagai kebutuhan, baik untuk konsumsi rumah tangga, maupun untuk kebutuhan sebagai bahan baku perusahaan industri, seperti industri minyak goreng.

Menurut Sarmidi (2009:1), tanaman kelapa (Cocos nucifera L) merupakan tanaman serbaguna yang mempunyai nilai ekonomi tinggi. Seluruh bagian pohon kelapa dapat dimanfaatkan untuk kepentingan manusia.hampir seluruh bagian pohon, dari akar, batang, daun sampai buahnya dapat digunakan untuk kebutuhan kehidupan manusia sehari-hari. Daun yang masih muda digunakan sebagai bungkus ketupat, hiasan ataupun bahan baku obat tradisional. Daun yang tua dianyam dan digunakan sebagai atap. 2

Kelapa merupakan tanaman yang serbaguna, artinya semua bagian tanaman memiliki nilai ekonomi sehingga tanaman ini sangat digemari oleh masyarakat. Disamping nilai ekonomi sehingga tanaman ini sangat digermari oleh masyarakat. Disamping nilai guna yang beragaman, kandungan gizi yang terdapat pada buah kelapa juga sangat tinggi.

\section{Identifikasi Masalah}

Berdasarkan latar belakang di atas maka dapat diturunkan masalah yaitu, apakah biaya pembelian buah kelapa butir dan biaya pengangkutan berpengaruh terhadap pendapatan pedagang pengumpul buah kelapa butir di Kecamatan Peureulak Barat Kabupaten Aceh Timur.

\section{Tujuan Penelitian}

Tujuan penelitian ini adalah untuk kelapa butir dan biaya pengangkutan terhadap pedagang pengumpul buah kelapa butir di Kecamatan Peureulak Barat Kabupaten Aceh Timur

\section{TINJAUAN PUSTAKA}

Usaha dagang buah kelapa merupakan salah satu kegiatan yang dilakukan oleh pedagang dalam rangka untuk mendapatkan pendapat atau keuntungan. Keuntungan yang diperoleh sangat berpengaruh pada biaya pemasaran, yang dalam hal ini biaya pembelian buah kelapa butir dan biaya pengangkutan, disamping itu kemampuan pedagang dalam mengelola kedua unsur biaya tersebut akan mempengaruh kelangsungan hidup usahanya.

Pengertian usaha dalam penelitian ini adalah kemampuan pedagang dalam mengelola beberapa faktor produksi dalam rangka untuk mendapatkan keuntungan atau pendapatan, yang dalam hal ini usaha dagang buah kelapa butir. Pendapat yang tinggi menunjukkan kinerja usaha dagang yang dijalankan pedagang sangat baik, dan dapat menjadi modal untuk periode mendatang. Kombinasi faktor-faktor produksi dapat menghasilkan pendapat bagi perusahaan, dan pendapatan tersebut akan digunakan oleh pengusaha untuk memebuhi kebutuhan keluarga pengusaha.

Biaya pemasaran akan mempengaruhi pendapatan pedagang. Adapun biaya pemasaran dalam penelitian ini adalah biaya pembelian buah kelapa butir dan biaya pengangkutan. Biaya pembelian buah adalah biaya yang dikeluarkan untuk mendapatkan buah kelapa butir dari petani produsen. Sedangkan biaya pengangkutan adalah biaya yang dikeluarkan oleh pedagang untuk memperlancar pergerakan buah kelapa dari petani produsen ke tempat usaha, atau biaya transprortasi ke pedagang besar di Sumatera Utara (Medan). Kedua biaya ini akan mempengaruhi pendapatan pedagang dalam menjalankan usahanya.

mengetahui pengaruh biaya pembelian buah AGRISAMUDRA, Jurnal Penelitian Vol. 2 No. I Januari-Juni 2015 
Jhon

(2013:4),

mengemukakan

pendapatan merupakan jumlah uang yang diterima oleh seseorang atau rumah tangga selama jangka waktu tertentu, pendapatan terdiri dari upah, atau penerima tenaga kerja, pendapatan dari kekayaan seperti (sewa, bunga dan deviden) serta pembayaran transfer atau penerima dari pemerintah, seperti tunjangan sosial atau asuransi pengangguran.

Biaya pemasaran yang dikeluarkan pedagang harus dilakukan dihitung semua agar total biayanya diketahui oleh pedagang harus dilakukan dihitung menghitung pendapatan pedagang untuk terus menjalankan usahanya, begitu juga sebaliknya.

Deden (2013:1), mengemukakan biaya pemasaran dalam arti sempit, yaitu biaya-biaya yang dikeluarkan untuk menjual dan membawa produk ke pasar. Sedangkan biaya pemasaran dalam arti luas, yaitu biaya-biya yang dikeluarkan sejak saat produksi selesai dan disimpan dalam gudang sampai produk tersebut berubah menjadi uang tunai.

Biaya pembelian buah kelapa akan memiliki hubungan yang sangta erat dengan pendapatan yang akan diperoleh, dimana semakin besar biaya yang dikeluarkan untuk membeli buah kelapa maka akan semakin besar kemungkinan untuk mendapat pendapat bagi pedagang. Begitu juga halnya dengan biaya pengangkutan, semakin kecil biaya pengangkutan yang dikeluarkan maka akan semakin besar pendapatan yang diperoleh.

Marwan (1991) dalam Sudayat (2012:1), mengemukakan "Penjualan merupakan sumber hidup suatu perusahaan, karena dari penjualan dapat diperoleh pendapatan atau keuntungan serta suatu usaha memikat konsumen yang diusahakan untuk mengetahui daya tarik mereka sehingga dapat mengetahui hasil produk yang dihasilkan". Sedangkan menurut Winardi (1982:4) dalam Sudayat (2012:3) "Penjualan adalah suatu transfer hak atas benda-benda. Dari penjelasan tersebut dalam memindahkan atau mentransfer AGRISAMUDRA, Jurnal Penelitian Vol. 2 No. I Januari-Juni 2015 barang dan jasa diperlukan orang-orang yang bekerja di bidang penjualan seperti pelaksanaan dagang, agen, wakil pelayanan dan wakil pemasaran".

Melalui kegiatan penjualan diperoleh pendapatan, setelah dikurangi beban biaya yang membebani terhadap perolehan produk yang dalam hal ini buah kelapa butir. Semakin besar volume penjualan maka akan semakin besar pendapat yang akan diperoleh, apabila beban biaya pemasaran dapat ditekan sekecil mungkin.

Swastha, (2004 : 403) penjualan adalah interksi antara individu saling bertemu mka yang ditujukan untuk menciptakan, memperbaiki, menguasai atau mempetahankan hubungan pertukaran sehingga menguntungkan bagi pihak lain. Penjualan dapat diartikan juga sebagai usaha yang dilakukan manusia untuk menyampaikan barang bagi mereka yang memerlukan dengan imbalan uang menurut harga yang telah ditentukan atas pertujuan bersama.

Pedagang dalam melakukan kegiatan usahanya harus mampu mencapai tujuan perusahan yaitu mendapat keuntungan atau pendapatan, yang dihitung dengan cara mengurangi antara hasil penjualan dengan beban biaya pemasaran selama kegiatan berjalan atau berlangsung. Kemampuan mengelola inilah yang menjadi pertanda usaha dagangannya berhasil atau tidak dalam periode waktu tertentu. Keberhasilan pedagang ditentukan oleh tingkat pendapatan yang diperoleh per periode waktu tertentu. Pendapatan yang diperoleh pedagang juga dipengaruhi oleh harga jual di saat dijual. Harga jual yang tinggi memang menjadi salah satu unsur motivasi pedagang dalam berusaha.

Pendapatan yang diperoleh pedangan setiap tahunnya sangat menentukan kebersihan usaha yang dijalankannya. Sebagai indikator keberhasilan tentu yang menjadi dasar adalah pendapat sangat berhasil, begitu juga sebaiknya semakin kecil pendapatan yang diperoleh 
usahanya dianggap gagal dalam pengelolaan usahanya.

Pendapatan usaha dagang disampng dipengaruhi biaya pembelian buah kelapa butir dan biaya pengangkutan, juga dipengaruhi oleh faktor lainnya yang tidak ikut diteliti dalam penelitian ini atau dianggap tetap (ceteris paribus), hal ini dituntun oleh hipotesa untuk memberikan batasan serta memperkecil jangkauan dan kerja peneliti.

\section{Hipotesis}

Sesuai dengan latar belakang masalah, tujuan peneltian dan kerangka pemikiran yang telah dikemukakan di atas, maka dapat dirumuskan hipeotesis sebagai berikut : "Biaya pembelian buah kelapa butir dan biaya pengangkutan berpengaruh terhadap pendapatan pengumpul pedagang kelapa butir di Keamatan Peureulak Barat Barat Kabupaten Aceh Timur.

\section{METODOLOGI PENELITIAN}

\section{Lokasi, Objek, Ruang Lingkup dan Waktu Penelitian}

Metode penelitian yang digunakan dalam penelitian ini adalah metode survey. Nazir (2005 : 550), "Metode survey adalah penyelidikan untuk memperoleh fakta dari gejala-gejala dan mencari keterangan-keterangan secara faktual, baik tentang isntitusi sosial, ekonomi ataupun politik dari suatu kelompok atau suatu daerah". Lokasi penelitian ini dilaksanakan di Kecamatan Peureulak Barat Kabupaten Aceh Timur dengan pertimbangan bahwa kecematan tersebut merupakan daerah yang terdapat usaha dagang kelapa butir.

Objek penelitian ini hanya dibatasi pada pedagang yang melakukan kegiatan usaha dagang kelapa butir di Kecamatan Peureulak Barat Kabupaten Aceh Timur. Ruang lingkup penelitian ini dibatasi pada biaya pembelian buah kelapa butir, biaya pengangkutan dan pendapatn usaha dagang kelapa butir di Kecamatan Peureulak Barat Kabupaten Aceh Timur. Waktu peneltian dilaksanakan pada bulan Oktober sampai dengan Nopember 2014. AGRISAMUDRA, Jurnal Penelitian Vol. 2 No. I Januari-Juni 2015
Teknik Penentuan Sampel dan Pengumpulan Data Penentuan Sampel

Kecamatan Peureulak Barat Kabupaten Aceh Timur terdiri dari 15 desa. Dari 15 desa tersebut hanya terdapat 8 desa yang melakukan usaha dagang kelapa butir yaitu Desa Beuringin, Desa Beusa Seberang, Paya Biek, Desa Paya Gajah, Desa Tanjug Tualang, Desa Mon Geudong, Desa Teumpeun, dan Desa Alue Bu Tunong. Dari 8 desa tersebut terdapat 15 orang pedagang yang semuanya dijadikan sebagai sampel dalam peneltian ini.

Penentuan sampel dilakukan dengan menggunakan metode Sensus yaitu semua populasi yang tersedia semuanya dijadikan sampel. Menurut Daniel (2002:41), "Metode sensus dikenal juga sebagai metode pencacahan lengkap. Artinya semua individu yang ada dalam populasi dicacah sebagai responden, Dicacah artinya diselidiki atau diwawancara".

\section{Pengumpulan Data}

Data yang dikumpulkan dalam penlitian ini dapat berupa data primer maupun data sekunder. "Data primer dalam penelitian ini dapat diperoleh dari pedagang responden dengan cara melakukan wawancara langsung dengan dari pedagang responden dengan menggunakan daftar pertanyaan (kuesioner) yang telah dipersiapakan sebelumnya.

Data sekunder diperoleh dari instansi terkait baik instansi Pemerintah Kabupaten Aceh Timur, Badan Pusat Statistik Kabupaten Aceh Timur, Kantor camat Kecamatan Peureulak Barat, Desa maupun Perpustakaan untuk mendapatan refensi yang ada kaitannya dengan penelitian ini.

\section{Variabel Data Yang Dianalisis}

Variabel data yang dianalisis dalam penelitian ini terdiri dari :
a. Luas Tempat Usaha (M2)
b. Penggunaan Tenaga Kerja (HKP/Tahun) 


\author{
c. Biaya Pembeli Buah Kelapa butir (Rp/Tahun) \\ d. Biaya Pengangkutan (Rp/Tahun) \\ e. Pendapatan (Rp/Tahun)
}

\section{Konsep Operasional Variabel}

a. Luas Tempat Usaha

Luas tempat usaha dalam penelitian ini adalah luas tempat usaha yang digunakan oleh pedagang untuk melaksanakan kegiatan usaha dagang kelapa butir yang diukur dalam satuan M2.

b. Penggunakan Tenaga Kerja

Penggunakan tenaga kerja dalam penelitian ini meliputi tenaga kerja dalam keluarga dan tenaga kerja luas keluarga, yang dihitung dengan menggunakan Hari Kerja Pria (HKP) per tahun.

c. Biaya Pembelian Buah Kelapa butir

Biaya pembelian buah kelapa butir adalah biaya yang dikeluarkan pedagang untuk membeli buah kelapa berupa harga beli kelapa perbutir dari petani dikalikan dengan jumlah kelapa yang dihitung dalam satuan rupiah per tahun.

d. Biaya Pengangkutan

Biaya pengangkutan adalah biaya yang dikeluarkan untuk keperluan transportasi buah kelapa butir, baik di dalam daerah maupun untuk luar daerah yang dihitung dalam satuan rupiah per tahun.

e. Pendapatan

Pendapatan dalam penelitian ini adalah pendapatan kotor dan pendapatan bersih.

- Pendapatan kotor adalah total nilai penjualan yang diperoleh pedagangan yang dihitung dalam satuan rupiah per tahun.

- Pendapatan bersih adalah selisih antara pendapatan kotor dengan total pengeluaran atau modal yang dikeluarkan pedagang yang diukur dengan rupiah per tahun.

\section{Metode Analisis dan Pengujian Hipotesis Analisis Data}

Data yang telah dikumpulkan di lapangan diolah yang selanjutnya dipindahkan ke dalam AGRISAMUDRA, Jurnal Penelitian Vol. 2 No. I Januari-Juni 2015 bentuk tabulasi, kemudia baru dipindahkan lagi ke dalam bentuk Tabelaris sesuai dengan kebutuhan analisis.

\section{Pengujian Hipotesis}

Hipotesis yang telah dirumuskan di atas akan diuji kebenarannya dengan menggunakan analisis regresi linear berganda, dengan satu variabel (Y) an dua variabel independen yaitu variabel (X1, dan X2). Model tersebut dapat ditulis sebagai berikut :

$Y=a 0+a 1 X 1+a 2 X 2$ ..(Sudjana, 2005 : 339)

Keterangan :

$\mathrm{Y}=$ Pendapatan (Rp/Tahun)

$\mathrm{X} 1$ = Biaya Pembelian Buah Kelapa butir (Rp/Tahun)

X2 = Biaya Pengangkutan (Rp/Tahun)

$\mathrm{aO}=$ Konstanta

a1 dan a2 adalah parameter yang dicari

Untuk melihat berapa besar pengaruh antara variabel $\mathrm{Y}$ terhadap variabel $\mathrm{X} 1$ dan $\mathrm{X} 2$ digunakan persamaan koefisien determinasi (R2) . Koefisien determinasi adalah besarnya keragaman (informasi) di dalam variabel $Y$ yang dapat diberikan oleh model regresi yang didapatkan. Untuk menguji pengaruh secara serempak variabel indenpenden (X1 dan X2) terhadap variabel dependen (Y), digunakan Uji F. .

Dengan kaidah keputusan ;

F hitung > F Tabel $(0,05)$ dan $(0,01)$ maka terima Ha dan tolak Ho

$\mathrm{F}$ hitung < F Tabel $(0,05)$ dan $(0,01)$ maka terima Ho dan tolak $\mathrm{Ha}$

Artinya :

$\mathrm{Ha}$ : secara serempak biaya pembelian buah kelapa butir (X1), dan biaya pengangkutan (X2) berpengaruh terhadap pendapatan $(\mathrm{Y})$.

Ho : secara serempak biaya pembelian buah kelapa butir (X1), dan biaya pengangkutan (X2) tidak berpengaruh terhadap pendapatan $(Y)$.

Untuk mengetahui pengaruh Variabel bebas terhadap Variabel Dependen secara parsial digunakan uji “t” . (Sunyoto, 2012:129), “analisis 
regresi parsial (individu) untuk mengetahui ada tidaknya pengaruh signifikan varibel bebas $(X)$ terhadap variabel terikat (Y)".

Dengan kaedah keputusan :

Jika t cari > t Tabel maka terima Ha dan tolak HO

Jika t cari < t Tabel maka terima $\mathrm{HO}$ dan tolak $\mathrm{Ha}$ Artinya :

Ha : Secara persial biaya pembelian buah kelapa butir (X1), dan biaya pengangkutan (X2) berpengaruh terhadap pendapatan $(\mathrm{Y})$.

Ho : Secara parsial biaya pembelian buah kelapa butir (X1), dan biaya pengangkutan (X2) tidak berpengaruh terhadap pendapatan $(\mathrm{Y})$.

\section{HASIL PENELITIAN DAN PEMBAHASAN Karakteristik Pedagang}

Karakteristik pedagang dalam penelitian ini meliputi umur, pendidikan, pengalaman berusahatani dan tanggungan keluarga. Keadaan karakteristik ini dapat mempengaruhi kegiatan dan kemampuan kerja pedagang dalam menjual kelapa butir. Rata-rata umur pedagang pengumpul di daerah penelitian yaitu berumur 36,20 tahun ini berarti petani di daerah penelitian masih dalam usia produktif, dengan pendidikan yaitu 10 tahun ini berarti pendidikan di daerah penelitian banyak yang menamatkan SLTP, dengan pengalaman berdagang yaitu rata-rata selama 6,87 tahun, dan dengan tanggungan keluarga rata-rata sebanyak 3 orang.

\section{Luas Tempat Usaha}

Luas tempat usaha yang dimaksud dalam penelitian ini adalah luas tanah dan bangunan tempat pedagang pengumpul melakukan usaha dagang kelapa. Luas tempat usaha berbeda antara pedagang satu dengan pedagang yang lainnya. Hal ini tergantung dari kemampuan modal dalam membiayai usaha dagangnya disamping faktor keberhasilan pada periode yang lalu.

Rata-rata luas tempat usaha pedagang pengumpul kelapa butir di daerah penelitian 20,33 m2. Luas tempat usaha terbesar terdapat di Desa AGRISAMUDRA, Jurnal Penelitian Vol. 2 No. I Januari-Juni 2015
Teumpun yaitu 32 M2, sedangkan luas lahan terkecil terdapat di Desa Tanjung Tualang sebesar $18 \mathrm{M} 2$.

\section{Penggunaan Tenaga Kerja}

Tenaga kerja merupakan salah satu faktor produksi yang sangat penting artinya dalam pemasaran kelapa. Penggunaan tenaga kerja yang efisien dan efektif dapat mempengaruhi terhadap pengeluaran biaya pemasaran dalam menjalankan dagangnya. Tenaga kerja yang digunakan pada usaha dagang pengumpul kelapa butir di daerah penelitian terdiri dari : Tenaga kerja pria, wanita dan anak-anak baik yang berasal dari dalam keluarga maupun luar keluarga. Untuk keseragaman tenaga kerja tersebut di konversikan ke dalam Hari Kerja Pria (HKP) Perbandingan Hari Kerja Wanita (HKW) dan Hari Kerja Anak (HKA) terhadap Hari Kerja Pria (HKP) dikonversikan ke dalam perbandingan yaitu untuk HKW perbandingan sebesar 0,8 HKP dan untuk HKA sebesar 0,5 HKP.

Total penggunaan tenaga kerja usahatani kelapa butir di daerah penelitian sejumlah 89,19 HKP/tahun. Penggunaan tenaga kerja terbesar terdapat pada jenis kegiatan pengangkutan/ transportasi sebesar 37,52 HKP/tahun. Sedangkan penggunaan tenaga kerja terkecil terdapat pada fase kegiatan penyortiran sebesar 25,30 HKP/tahun.

\section{Biaya Pemasaran}

Biaya pemasaran di daerah penelitian terbagi atas dua jenis yaitu biaya tetap (Fixed cost) dan biaya variabel (Variable cost). Biaya tetap yaitu biaya yang tidak habis dipakai pada satu kali proses produksi, sedangkan biaya variabel yaitu biaya yang habis sekali pakai pada proses produksi.

Biaya tetap terdiri dari biaya sewa tempat usaha, dan biaya penyusutan alat yang dipakai pada kegiatan usaha. Biaya variabel terdiri dari biaya pembelian kelapa butir, biaya tenaga kerja, 
biaya sewa alat transportasi dan biaya bahan bakar alat transportasi yang digunakan dalam usaha pembelian kelapa butir.

Rata-rata penggunaan biaya pemasaran usaha pedagang pengumpul kelapa butir di daerah penelitian sebesar Rp. 265.219.766,67/Usaha /Tahun. Penggunaan biaya paling besar terdapat di Desa Teumpun sebesar Rp. 326.647.000,00/Usaha /Tahun dengan biaya tetap sebesar Rp. 7.595.000,00/ Usaha/Tahun dan biaya variabel sebesar Rp. 319.052.000,00/ Usaha/Tahun.

Sedangkan penggunaan biaya paling kecil terdapat di Desa Paya Biek sebesar Rp. 220.725.500,00 /Usaha/Tahun, dengan biaya tetap Rp. 7.095.500,00/ Usaha/Tahun dan biaya variabel Rp. 213.630.000,00/ Usaha/Tahun.

\section{Pendapatan Kotor}

Pendapatan kotor adalah jumlah total pendapatan yang diterima oleh seorang pengusaha sebelum dikurangi biaya biaya produksi atau modal.

Pendapatan kotor dalam penelitian ini adalah pendapatan yang diterima oleh pedagang pengumpul kelapa butir sebelum dikurangi biaya pemasaran atau modal. Atau dengan kata lain jumlah kelapa yang dibeli dikalikan harga jual kelapa.

Harga jual kelapa butir yang berlaku pada waktu penelitian adalah Rp. 2.463,33 /butir dengan harga beli sebesar Rp. 1.683/Butir.

Rata-rata pendapatan kotor yang diterima pedagang pengumpul kelapa butir di dearah penelitian adala sebesar Rp. 314.814.000,00/Usaha/Tahun. Pendapatan kotor terbesar terdapat di Desa Teumpun sebesar Rp. 434.160.000,00/Usaha/Tahun.

Sedangkan pendapatan kotor terkecil terdapat di Desa Paya Biek sebesar Rp. 312.000.000,00/Usaha/Tahun.

\section{Pendapatan Bersih}

Pendapatan adalah selisih antara nilai produksi atau pendapatan kotor dengan total biaya pemasaran.

Rata-rata pendapatan bersih yang diterima pedagang pengumpul kelapa butir di daerah penelitian adalah sebesar Rp. 92.308.100,00 /Usaha/Tahun. Pendapatan bersih terbesar terdapat di Desa Teumpun sebesar Rp. 107.513.000,00/Usaha/Tahun.

Sedangkan pendapatan kotor terkecil terdapat di Desa Tanjung Tualang sebesar Rp. 79.997.000,00 /Usaha/Tahun.

\section{Biaya Pembelian}

Biaya pembelian yang dimasud dalam penelitian ini adalah Jumlah kelapa yang dibeli pedagang kelapa butir dikalikan dengan harga beli kelapa yang dihitung dalam satuan rupiah per tahun. Rata-rata harga beli kepala yang berlaku pada saat dilakukan penelitian adalah $\mathrm{Rp}$. 1.683/Butir.

Rata-rata biaya pembelian kelapa butir di daerah penelitian adalah sebesar Rp. 229.574.000,00

Usaha/Tahun. Biaya pembelian terbesar terdapat di Desa Teumpun sebesar Rp. 289.440.000,00/Usaha/ Tahun. Sedangkan biaya pembelian kelpa butir terkecil terdapat di Desa Tanjung Tualang sebesar Rp. 193.920.000,00 /Usaha/Tahun.

\section{Biaya Pengangkutan}

Biaya pengangkutan yang dimaksud dalam penelitian ini adalah total biaya yang dikeluarkan pedagang pengumpul kelapa untuk mengangkut atau mendistribusikan kelapa yang dihitung dalam satuan rupiah per tahun. Biaya pengangkutan dalam penelitian ini terdiri dari biaya tenaga kerja, biaya sewa alat transportasi dan biaya bahan bakar transportasi.

Rata-rata biaya pengangkutan kelapa di daerah penelitian adalah sebesar Rp. 25. 434.533,33/Usaha/Tahun. Biaya pengangkutan 
terbesar terdapat di Desa Teumpun sebesar Rp. 26.252.000,00 /Usaha/Tahun. Sedangkan biaya pengangkutan terkecil terdapat di Desa Tanjung Tualang sebesar Rp. 23.580.000,00 /Usaha/Tahun.

Pengaruh Biaya Pemasaran Terhadap Pendapatan Pedagang Pengumpul Kelapa Butir (Cocos nucifera, L) Kecamatan Peureulak Barat Kabupaten Aceh Timur

Faktor-faktor yang mempengaruhi pendapatan pedagang pengumpul kelapa butir di Kecamatan Peureulak Barat Kabupaten Aceh Timur adalah biaya pembelian kelapa dan biaya pengangkutan sedangkan faktor-faktor lain dianggap tetap (ceteris paribus). Untuk mengetahui besarnya pengaruh tersebut, maka dianalisis dengan menggunakan regresi linear berganda, sehingga diperoleh persamaan regresi sebagai berikut :

$Y=4,87+0,201 X 1-0,103 X 2$

Dari persamaan regresi dapat disimpulkan bahwa :

a. Setiap penambahan Rp. 1.000.000,00,- biaya pembelian kelapa maka pendapatan pedagang pengumpul kelapa butir bertambah Rp. 201.000,00,--

hal ini terjadi karena semakin tinggi biaya yang dikeluarkan untuk membeli kelapa maka jumlah kelapa yang dibeli akan semakin banyak sehingga pendapatan yang diperoleh akan besar juga.

b. Setiap penambahan Rp. 1.000.000,00,- biaya pengangkutan kelapa maka pendapatan pedagang pengumpul kelapa berkurang Rp. 103.000,00,-. Hal ini

terjadi karena dengan besarnya biaya pengangkutan kelapa maka biaya pemasaran kelapa akan besar juga sehingga mengurangi jumlah pendapatan yang diperoleh.

Dari perhitungan diperoleh $(\mathrm{R} 2)=0,547$ atau 54,7 \%. Ini berarti biaya pembelian kelapa dan biaya pengangkutan kelapa berpengaruh terhadap pendapatan sebesar 54,7 \% sedangkan 45,3\% AGRISAMUDRA, Jurnal Penelitian Vol. 2 No. I Januari-Juni 2015 dipengaruhi oleh faktor-faktor lainnya yang tidak diteliti dalam penelitian ini, diantaranya jumlah tenaga kerja kerja yang digunakan, modal, harga jual dan lain-lain.

Hasil pengujian secara serempak diperoleh Fcari $=7,237$ dengan FTabel 3,89 pada tingkat kepercayaan $95 \%$ dan 6,93 pada tingkat 99 \%. Ini berarti secara serempak ada pengaruh yang sangat nyata antara biaya pembelian kelapa dan biaya pengangkutan kelapa terhadap pendapatan pedagang pengumpul kelapa butir di Kecamatan Peureulak Barat Kabupaaten Aceh Timur.

Hasil pengujian signifikan secara parsial dilakukan dengan uji t, dimana hasil dari pengujian pada parameter X1 dan X2 diperoleh hasil sebagai berikut :

- tcari untuk t1sebesar 33,294 dengan tTabel 1,78 pada tingkat kepercayaan $95 \%$ dan 2,68 pada tingkat $99 \%$ (tTabel $\alpha 0,05<$ tcari>tTabel $\alpha 0,01$ ) . maka terima $\mathrm{Ha}$ dan tolak Ho. Artinya secara Parsial biaya pembelian berpengaruh sangat nyata terhadap pendapatan pedagang pengumpul kelapa butir.

- tcari untuk t2 sebesar -0,017 dengan tTabel 1,78 pada tingkat kepercayaan $95 \%$ dan 2,68 pada tingkat $99 \%$ (tTabel $\alpha 0,05>$ tcari<tTabel $\alpha 0,01$ ) . maka terima Ho dan tolak $\mathrm{Ha}$. Artinya secara parsial biaya pengangkutan kelapa tidak berpengaruh terhadap pendapatan pedagang pengumpul kelapa butir.

\section{Pembahasan}

a. Biaya pembelian kelapa berpengaruh sangat nyata terhadap pendapatan pedagang kelapa terjadi karena semakin besar biaya pembelian yang digunakan maka semakin banyak kelapa yang dapat dibeli, dengan banyaknya kelapa yang dibeli maka keuntungan yang didapat oleh pedagang semakin besar juga.

b. Biaya pengangkutan tidak berpengaruh terhadap pendapatan pedagang kelapa terjadi karena biaya pengangkutan yang dikeluarkan pedagang di daerah penelitian tidak tergantung pada jumlah 
kelapa yang diangkut, tapi biayanya dihitung per sekali alat transportsi mengangkut kelapa (alat transportasi disewa).

\section{KESIMPULAN DAN SARAN}

\section{Kesimpulan}

a. Rata-rata umur pedagang pengumpul di daerah penelitian yaitu berumur 36,20 tahun ini berarti petani di daerah penelitian masih dalam usia produktif, dengan pendidikan yaitu 10 tahun, dengan pengalaman berdagang yaitu rata-rata selama 6,87 tahun, dan dengan tanggungan keluarga rata-rata sebanyak 3 orang. Rata-rata luas tempat usaha pedagang pengumpul kelapa butir di daerah penelitian 20,33 m2.

b. Total penggunaan tenaga kerja usahatani kelapa butir di daerah penelitian sejumlah 89,19 HKP/Tahun atau 29,73HKP/usaha/Tahun. Ratarata penggunaan biaya pemasaran usaha pedagang pengumpul kelapa butir di daerah penelitian sebesar Rp. 265. 219.766,67 /Usaha/Tahun. Rata-rata pendapatan kotor yang diterima pedagang pengumpul kelapa butir di dearah penelitian adala sebesar Rp. 314.814.000,00/Usaha/Tahun. Rata-rata pendapatan bersih yang diterima pedagang pengumpul kelapa butir di dearah penelitian adalah sebesar Rp. 92.308.100,00/Usaha/Tahun.

c. Rata-rata biaya pembelian kelapa butir di daerah penelitian adalah sebesar Rp. 229.574.000,00 /Usaha/Tahun. Rata-rata biaya pengangkutan kelapa di daerah penelitian adalah sebesar Rp. 25.434.533,33 /Usaha/Tahun.

d. Hasil perhitungan regresi linear berganda, sehingga diperoleh persamaan regresi sebagai berikut : $Y=4,87+0,201 \times 1-0,103 \times 2$. Dari persamaan regresi dapat disimpulkan bahwa : “ Setiap penambahan Rp. 1.000.000,00,- biaya pembelian kelapa maka pendapatan pedagang pengumpul kelapa butir bertambah $\mathrm{Rp}$. 201.000,00,-, dan setiap penambahan Rp. 1.000.000,00,- biaya pengangkutan kelapa maka pendapatan pedagang pengumpul kelapa berkurang Rp. 103.000,00,-.

e. Dari perhitungan diperoleh $(\mathrm{R} 2)=0,547$ atau 54,7 \%. Ini berarti biaya pembelian kelapa dan biaya pengangkutan kelapa berpengaruh terhadap pendapatan sebesar 54,7 \% sedangkan 45,3\% dipengaruhi oleh faktor-faktor lainnya yang tidak diteliti dalam penelitian ini, diantaranya luas lahan, pendidikan dan jumlah produksi yang diperoleh. $f$. Hasil pengujian secara serempak diperoleh Fcari $=$ 7,237 dengan Ftabel 3,89 pada tingkat kepercayaan $95 \%$ dan 6,93 pada tingkat $99 \%$. Ini berarti secara serempak ada pengaruh yang sangat nyata antara biaya pembelian kelapa dan biaya pengangkutan kelapa terhadap pendapatan pedagang pengumpul kelapa butir di Kecamatan Peureulak Barat Kabupaaten Aceh Timur.

g. Hasil pengujian signifikan secara parsial dilakukan dengan uji t, dimana hasil dari pengujian pada parameter X1 dan X2 diperoleh hasil sebagai berikut :

- tcari untuk t1sebesar 33,294 dengan ttabel 1,78 pada tingkat kepercayaan 95\% dan 2,68 pada tingkat $99 \%$ (ttabel $\alpha 0,05<$ tcari>ttabel $\alpha 0,01$ ) .maka terima $\mathrm{Ha}$ dan tolak Ho. Artinya secara Parsial biaya pembelian berpengaruh sangat nyata terhadap pendapatan pedagang pengumpul kelapa butir.

- tcari untuk t2 sebesar -0,017 dengan ttabel 1,78 pada tingkat kepercayaan $95 \%$ dan 2,68 pada tingkat $99 \%$ (ttabel $\alpha 0,05>$ tcari<ttabel $\alpha 0,01$ ) . maka terima Ho dan tolak Ha. Artinya secara parsial biaya pengangkutan kelapa tidak berpengaruh terhadap pendapatan pedagang pengumpul kelapa butir.

\section{Saran}

a. Dalam upaya peningkatan pedapatan, khsusnya pedagang pengumpul kelapa,

selain meningkatkan jumlah pembelian kelapa butir dan meminimalkan biaya

pemasaran, perlu juga hendaknya memanfaatkan peluang harga yang 
ditawarkan untuk produk yang diinginkan oleh konsumen yang dapat memberi nilai lebih.

b. Perlu adanya penambahan modal dalam usaha pembelian kelapa butir dan diharapkan adanya juga dukungan pemerintah dalam menangani harga bahan

bakar. Karena dengan tingginya harga bahan bakar maka biaya pemasaran suatu barang khususnya kelapa akan tinggi juga.

\section{DAFTAR PUSTAKA}

Amang, B., dkk., 1996. Ekonomi Minyak Goreng di Indonesia. IPB Press, Bogor.

Anonimius., 2009. Kelapa. http://id.wikipedia.org [7 Februari 2009]

Azzaino, 1982, Pengantar Tata Niaga Pertanian. Departemen IImu-ilmu Sosial Ekonomi. Fakultas Pertanian, Institut Pertanian Bogor. Bogor

Azmil., 2006. Peluang Investasi Tanaman Kelapa di Provinsi Sumatera Utara. http://www.bainfokomsumut.go.id [7 Februari 2009]

Boyd, H., dkk., 2000. Manajemen Pemasaran. Erlangga, Jakarta.

Daniel, M., 2002. Pengantar Ekonomi Pertanian. Bumi Aksara, Jakarta.

Gitosudarmo, I. 2001, Manajemen Pemasaran, BPFE, Yokyakarta.

Hanafiah, A.K dan I.B. Taken. 1972, Tata Niaga Pertanian. Institut Pertanian Bogor. Bogor.

Kotler. P.,1993. Manajemen Pemasaran Jilid I. Erlangga, Jakarta.

Rahim, A., 2007. Ekonomika Pertanian. Penebar Swadaya, Jakarta.

Rangkuti, Freddy, 2002, Creating Effective marketing Plan, Gramedia Pustaka Utama, Jakarta.

Setyamidjaja, D., 1985. Bertahan Kelapa Hibrida. Kanisius, Yogyakarta

Soekartawi., 2002. Prinsip Dasar Manajemen Pemasaran Hasil-hasil Pertanian.

Raja Grafindo Persada, Jakarta.

Suhardiman, P., 1999. Bertanam Kelapa Hibrida. Penebar Swadaya, Bogor

Suhardiyono, L., 1995. Tanaman Kelapa Budidaya dan Pemanfaatannya. Kanisius, Yogyakarta 